\title{
PHYSIOLOGICAL CHARACTERIZATION AND CONSERVATION OF SEEDS OF Eugenia candolleana (MYRTACEAE)
}

\author{
Kelli Pirola ${ }^{1}$, Marcelo Dotto ${ }^{1}$, Darcieli Aparecida Cassol $^{1}$, Américo Wagner Júnior ${ }^{1}$, Sérgio Miguel \\ Mazaro $^{1}$, Idemir Citadin ${ }^{1}$
}

${ }^{1}$ Universidade Tecnológica Federal do Paraná.E-mail: kelli_pirola1@hotmail.com; marcelodotto@ hotmail.com; so_darci@hotmail.com; americowagner@utfpr.edu.br; sergio@utfpr.edu.br; idemir@utfpr.edu.br

\begin{abstract}
Eugenia candolleana, popularly known as forest plum tree, has potential for use in market that look for new products, but little is known about it. The objective of this work was to study the physiological behavior of E. candolleana seeds. Two experiments were carried out: the first determine the moisture content tolerable by the seeds and the second verified presence of seed dormancy. The experiments were installed in a completely randomized design with four replicates of 100 seeds. Reducing the moisture content of seed reduced its viability and it should not lower their initial content more than $20 \%$. E. candolleana seeds did not present dormancy. The use of sulfuric acid conditions is not recommended.
\end{abstract}

Keywords: Sexual propagation, dormancy, moisture content

\section{CARACTERIZAÇÃO FISIOLÓGICA E CONSERVAÇÃO DE SEMENTES DE Eugenia candolleana (MYRTACEAE)}

\section{RESUMO}

Eugenia candolleana, conhecida popularmente como ameixeira-da-mata, possui potencialidade para uso em nichos de mercado ávidos por novidades, porém pouco se conhece sobre a mesma. $\mathrm{O}$ objetivo deste trabalho foi estudar o comportamento fisiológico de sementes de Eugenia candolleana. Foram realizados dois experimentos, sendo o primeiro para determinar o teor de umidade tolerável pelas sementes, e o segundo para verificar a dormência nas sementes. Os experimentos foram instalados em delineamento inteiramente casualizado, com quatro repetições de 100 sementes. A redução do teor de umidade das sementes de ameixa-da-mata reduziu a viabilidade das mesmas, não devendo-se baixar mais 
do que $20 \%$ seu teor inicial. As sementes de ameixa-da-mata não apresentam dormência. Não é recomendado o uso de ácido sulfúrico em ambas as condições de fotoperíodo estudadas neste trabalho.

Palavras-chave: Propagação sexuada, dormência, teor de umidade

\section{INTRODUCTION}

The Brazilian flora is rich in species that present edible fruits, however, in South Brazil, the Myrtaceae family highlights, with a great potential for economic exploitation (MANICA, 2002), but still incipient due to low production and to be limited to certain regions (FRANZON et al., 2009).

This potential for commercialization is due to the sensorial and functional characteristics of the fruits produced, the latter attracting the attention of the pharmaceutical industries, since they have high concentration of vitamins and antioxidants, as well as essential oils, which can also be extracted from leaves and other parts of the plant (MAGALHÃES et al., 1996; MARIN et al., 2004).

The native fruits that have already demonstrated this antioxidant action were Psidium guajava (guava) (MELO et al., 2008a), Annona crassiflora (araticum), Eugenia dysenterica (cagaita) (ROESLER et al., 2007), Eugenia uniflora (Surinan cherry) (MELO et al., 2008b), Eugenia pyriformis Camb. (Uvaia), Eugenia involucrata DC. (Cerejeira-do-mato) and Plinia spp. (jabuticaba) (RUFINO et al., 2010, 2011; LIMA et al., 2011; LEITE-LEGATTI et al., 2012).

However, despite all this potential, the only existing commercial orchards with native fruit trees refer to guava, pineapple and passion fruit. Thus, it is necessary to create orchards that involve the other native fruit trees, especially when it refers to Eugenia candolleana, already that it may attract markets that look for new things. The fruits of this species are black, bright, globular or oblong, with a firm thick pulp, very sweet taste, reaching maturation from February to March (LORENZI et al., 2006), period when only few fruits are harvested per tree. In addition, this fruit presents great potential for use as jelly according to the sensorial analysis described by Cassol et al. (2012), in which it presented greater acceptability by tasters when compared to fig jam. However, to make possible the creation of these orchards it is firstly necessary to produce quality seedlings. For this, studies need to be done regarding the best way to obtain them, characterizing the physiological behavior of their seeds regarding storage and germination. This involves trying obtain information about acceptable moisture content of the seed, if there is seed dormancy and if it can be stored for a long time without loss of viability. Once with such information it is possible to use in orchards and perhaps in the near future to create breeding programs. 
The objective of this work was to study the physiological behavior of E. candoleana, in relation to storage and germination process.

\section{MATERIAL AND METHODS}

Two experiments were carried out at the Plant Physiology Laboratory of the Universidade Tecnológica Federal do Paraná - Campus Dois Vizinhos, State of Paraná, Brazil. Seeds of physiologically mature fruits of E. candoleana collected on March 2012 from the university orchard were used. For the extraction of these seeds the pulp was manually removed and later washed in running water. Then they were laid out on paper towel, where they remained for 24 hours in shade to remove excess of moisture.

After 60 days of the first germinated seed, in both experiments, the percentage of germination (G\%) according to RAS (BRAZIL, 2009); germination speed index (GSI) following the methodology proposed by Maguire (1962), calculated by the formula GSI $=\Sigma(\mathrm{ni} / \mathrm{ti})$, where ni $=$ number of seeds that germinated each day and $\mathrm{t} i=$ day the seed germinated; percentage of accumulated germination $(\mathrm{AG} \%)$ and average germination time (AGT), according to Silva \& Nakagawa (1995), calculated by the formula $\mathrm{AGT}=(\Sigma$ niti $) / \Sigma$ ni, where ni $=$ number of seeds germinated per day and $\mathrm{t} i=$ day the seed germinated, were evaluated.

The experimental design used in both experiments was completely random, with four replicates of 100 seeds. The germination, germination speed index (GSI) and AGT data were previously submitted to the Lilliefors' normality test, with the data was transformed by arc seno $\sqrt{x / 100}$ for germination and AGT and $\sqrt{x+1}$ for GSI. There were data transformation for the variables, GSI and AGT in both experiments and for germination in experiment 2. The averages were submitted to analysis of variance and Tukey's test $(\alpha=0.05)$. All analyzes of dates were performed by the computational application SANEST® (ZONTA \& MACHADO, 1984).

For the determination of the moisture content, after drying the seeds (for 24 hours), they were weighed in analytical balance, obtaining the mass of the initial fresh matter of the seeds. After, the seeds were soaked in distilled water, remaining in this condition until constant weight, after they were again weighed, obtaining the mass of turgid material, that is, mass with maximum accumulated water content ( \pm 96 hours). The seeds were then placed in Petri® plates and subjected to slow dehydration in a Biochemical Oxigen Demand (B.O.D) chamber at $25^{\circ} \mathrm{C}$ for periods of $0,6,24,48,72,96,120,144,168$, 192, 216, and 240 hours. After each period, each batch of seeds was weighed again, obtaining the final 
fresh matter mass (P3). The seeds were then seeded in a plastic tray $(18 \times 12 \mathrm{~cm})$ containing sand as substrate. After the sowing, the trays were kept in a phytotron chamber at $25^{\circ} \mathrm{C}$ (WAGNER JÚNIOR et al., 2007), daily checking the moisture content of the substrate and when necessary it was moistened with distilled water. The moisture content of the seed was determined by multiplying the mass of the final fresh matter of the seeds by 100 and dividing them by the value obtained by the mass of the turgid material.

After extraction, the seeds were separated into two lots, according to the submission of each photoperiod (with or without). Afterwards, both photoperiod lots were separated into sublots, which were used the treatments: T1 - No use of dormancy breaking; T2 - Gibberellic acid (200 $\left.\mathrm{mg} \mathrm{L}^{-1}\right)$ for one hour; $\mathrm{T} 3$ - Stratification at $5^{\circ} \mathrm{C}$ for 30 days; T4 - Immersion in water at room temperature for 24 hours; T5 Chemical scarification with sulfuric acid (96\%) for 5 minutes; T6 - Scarification with sandpaper; T7 Immersion in hot water $\left(80^{\circ} \mathrm{C}\right)$ for 5 minutes.

The concentration of gibberellic acid $\left(\mathrm{GA}_{3}\right)$ used was prepared from the commercial product ProGibb®, which contains $10 \%$ active principle of this phytoregulator. The volume of water used in the water immersion tests was four times that of the seed and twice that of sulfuric acid.

After the application of each technique described in the sublots, the seeds were placed in Gerbox boxes on Germtest ${ }^{\circledR}$ paper and kept in a B.O.D. chamber, using a controlled temperature of $25^{\circ} \mathrm{C}$ (WAGNER JÚNIOR et al., 2007), without and with photoperiod (zero and 24 hours with light, respectively), which constituted lots one and two, respectively. The averages were submitted to analysis of variance and Tukey's test $(\alpha=0.05)$. All data was evaluated by the computational application SANEST® (ZONTA \& MACHADO, 1984).

\section{RESULTS AND DISCUSSION}

The seeds started the germination process at 30 days after the implantation of the experiment. The moisture at the time of the seed extraction was $74.1 \%$. The moisture content lost according to the drying time is in Table 1.

It should be emphasized that all seeds before being subjected to drying were previously dampened for 96 hours, therefore the highest values of moisture at the begin are because it was assumed that in the time of zero hour all were with maximum moisture content. 
Table 1. Water loss (\%) of E. candoleana seeds at the time of sowing, according to their drying time.

\begin{tabular}{c|c}
\hline Drying time (hours) & Water loss (\%) \\
\hline 0 & 0,0 \\
24 & 3,4 \\
48 & 7,0 \\
72 & 9,6 \\
96 & 15,2 \\
120 & 16,4 \\
144 & 19,7 \\
168 & 21,0 \\
192 & 22,6 \\
216 & 23,3 \\
240 & 24,8 \\
\hline
\end{tabular}

The germination and GSI of E. candoleana seeds (Figures 1A and 1B, respectively) presented statistical differences between the drying times, both curves showing an increase in their values until a certain time, followed by a fall, which constituted the maximum point, obtained with 77 hours of drying, in which $45 \%$ of germination (Figure 1A) were obtained. At this maximum calculated point, the seeds had moisture contents close to $80 \%$ (Table 1).

For GSI, the maximum point was obtained in the drying time of 31 hours, presenting GSI values of 2.76 (Figures 1B), whose humidity was close to $90 \%$ (Table 1).

For AGT, there were statistically significant differences between the drying times, presenting increasing quadratic behavior, the minimum point being obtained with 74 hours of drying, at this point a germination time of 20 days (Figure 1C), where the humidity was near to $85 \%$ (Table 1). 


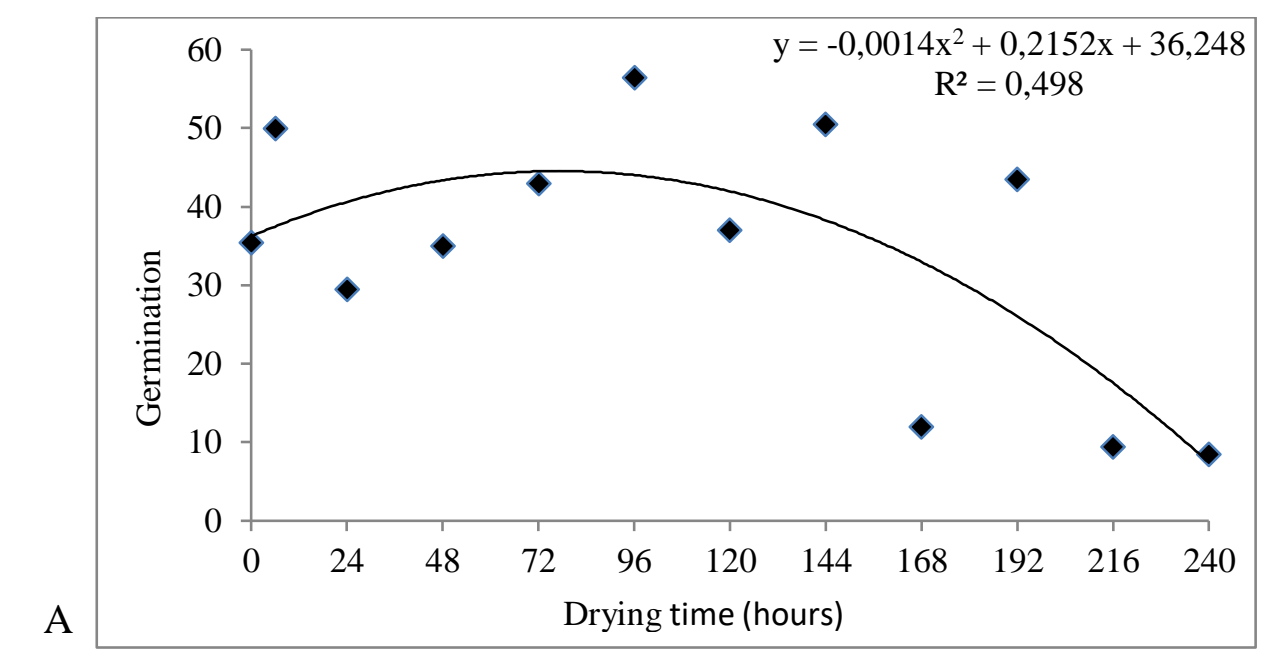

A

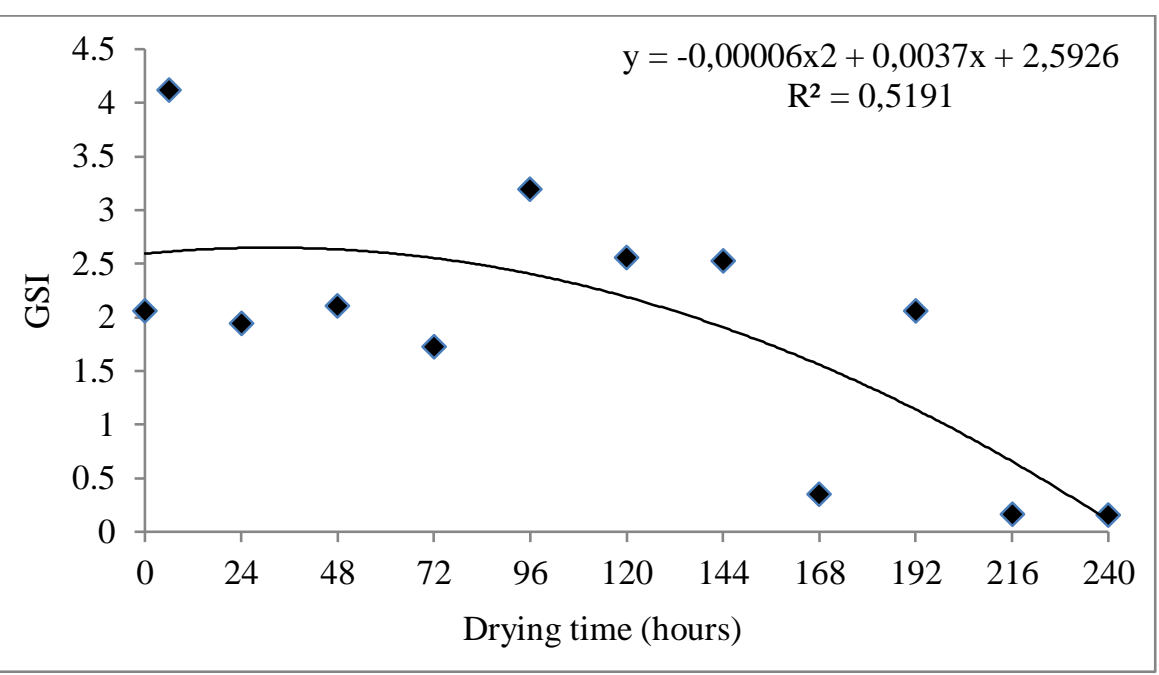

B

$$
\begin{gathered}
Y=0,0006 x 2-0,0892 x+23,168 \\
R^{2}=0,6944
\end{gathered}
$$
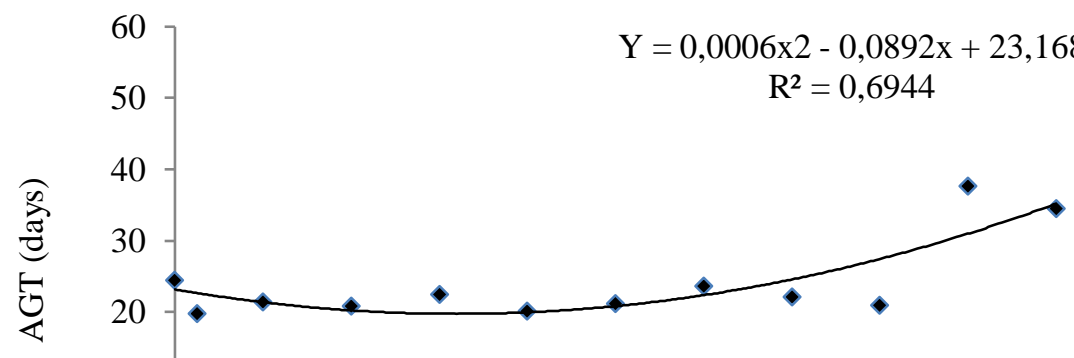

$\mathrm{C}$

Drying time (hours)

Figure 1. Germination (\%) (Figure A), germination speed index (GSI) (Figure B) and average germination time (days) (AGT) (Figure C), of E. candoleana seeds accordingly the drying time. 
According to Delgado \& Barbedo (2007), the seeds belonging to the genus Eugenia (E. barsiliensis Lam., E. cerasiflora Miq., E. involucrata DC., E. pyriformis Camb., E. umbelliflora Berg.) began to lose their viability when they present losses of humidity around 15 to 20 percentage. It was verified that the seeds lost more than 19,7 percentage points in the water content after 120 hours of drying (Table 1), which may have interfered to reduce germination and GSI values, and increase in AGT.

Seeds of species of the genus Eugenia, such as E. dysenterica (ANDRADE et al., 2003) and E. stipitata ssp. Sororia (GENTIL \& FERREIRA, 1999), present themselves as sensitive to drying, even when small reductions occur in their moisture content.

The decrease in the values of germination and GSI and increase in the AGT of the seeds of this fruit tree proved that the seeds lost their viability with drying, it is considered sensitive to drying. The same classification was framed for Plinia sp. (VALIO \& FERREIRA, 1992), which are described as recalcitrant.

The loss of water in recalcitrant seeds triggers some deteriorating processes, such as protein denaturation, changes in peroxidase enzyme activity and membrane system damage, resulting in complete loss of viability (NAUTIYAL \& PUROHIT, 1985). The E. candoleana seeds need more attention if stored for a certain period, since they demonstrated this sensitivity to desiccation.

This short longevity restricts the term of their use, being necessary to realize the sowing soon after its extraction of the fruits (STUBSGAARD, 1990) or to study ways to conserve them for a longer period.

The seed AGT in the shortest periods was shorter than in the longer drying times (Figures 1C). The evaluation of the germination test for up to 60 days after the beginning of the germination process allowed. On one hand, the observation of a high percentage of germination, mainly in the shortest drying times of the seeds, however, on the other hand, it was obtained higher values for the AGT.

Scalon (2012), evaluating times of sensitivity to desiccation in Eugenia pyriformis seeds, which is also an important fruit tree native to of Myrtaceae family, observed an average for the AGT of 60 days when stored in a refrigerator and 66 days for those that were not stored. This fact demonstrates the high AGT value also verified for E. candoleana. This high AGT observed is due to the fact of the delay in starting the germination, being around 30 days to start.

After germination $\left(30^{\text {th }}\right.$ day), the percentage of germinated seeds was increased up to a certain period, stabilizing basically at 60 days (Figure 2). Therefore, it is possible to establish such range as 
indicated to evaluate the germination of E. candoleana, since there is no information in literature about it.

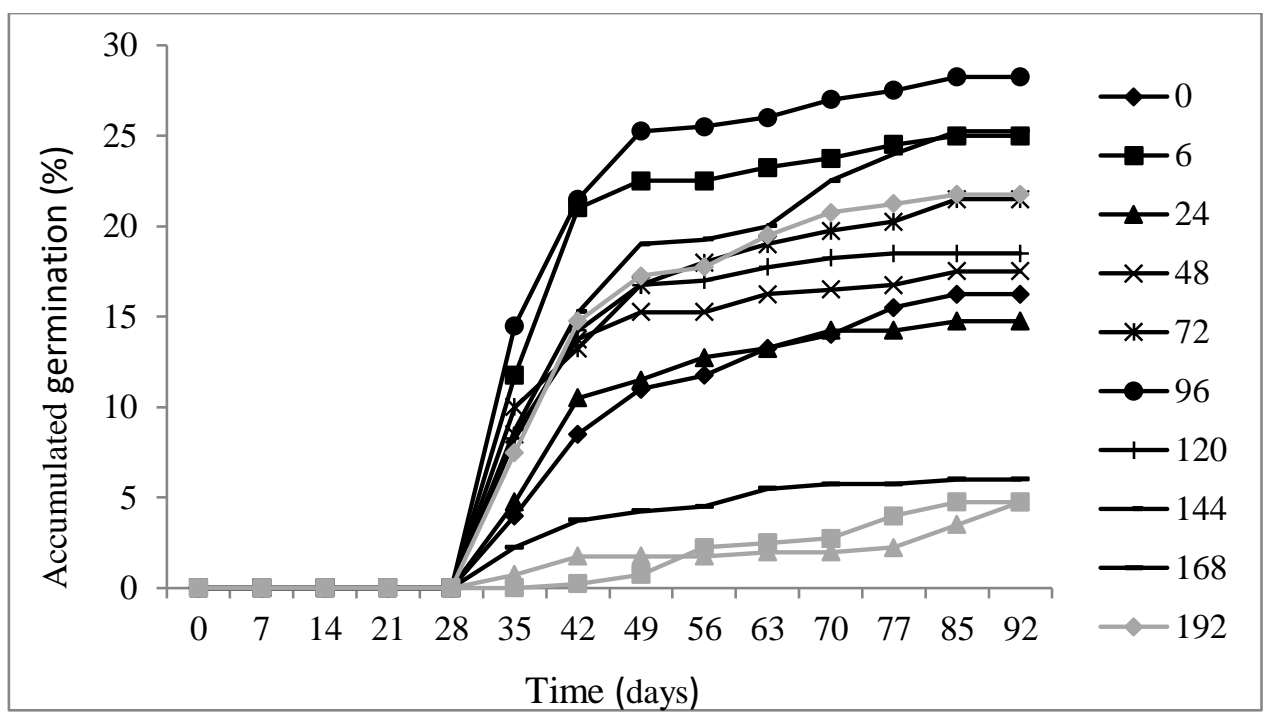

Figure 2. Accumulated germination (\%) of E. candoleana seeds, according to the drying time of the seeds.

The interaction luminosity $\mathrm{x}$ technique to break dormancy was significant for germination, GSI and AGT of plum seeds (Tables 2, 3 and 4, respectively).

Table 2. Germination $(\%)$ of E. candoleana seeds according to the photoperiod and technique for breaking dormancy.

\begin{tabular}{ccc}
\hline \multicolumn{3}{c}{ Photoperiod } \\
\hline Treatments & 0 hours & 24 hours \\
\hline T1 $^{(1)}$ & $72.25 \mathrm{aA}^{*}$ & $0.89 \mathrm{cB}$ \\
T2 & $70.50 \mathrm{aA}$ & $28.42 \mathrm{bB}$ \\
T3 & $4.34 \mathrm{cA}$ & $0.00 \mathrm{cB}$ \\
T4 & $81.40 \mathrm{aA}$ & $55.38 \mathrm{aB}$ \\
T5 & $0.00 \mathrm{dA}$ & $0.00 \mathrm{cA}$ \\
T6 & $75.41 \mathrm{aA}$ & $62.71 \mathrm{aA}$ \\
T7 & $49.14 \mathrm{bA}$ & $0.45 \mathrm{cB}$ \\
\hline
\end{tabular}

$\mathrm{CV}(\%)$

(1) T1 - No use of dormancy breaking; T2 - Gibberellic acid $\left(200 \mathrm{mg} \mathrm{L}^{-1}\right)$ for one hour; T3 - Stratification at $5^{\circ} \mathrm{C}$ for 30 days; T4 - Immersion in water at room temperature for 24 hours; T5 - Chemical scarification with sulfuric acid (96\%) for 5 minutes; T6 - Scarification with sandpaper; T7 - Immersion in hot water $\left(80^{\circ} \mathrm{C}\right)$ for 5 minutes.

*Averages with different lowercase letters in the same column and upper case in row differ by Tukey's test $(\alpha=0.05)$. 
Table 3. Germination speed index (GSI) of E. candoleana seeds according to the photoperiod and technique for breaking dormancy.

\section{Photoperiod}

\begin{tabular}{|c|c|c|}
\hline Treatments & 0 hours & 24 hours \\
\hline $\mathrm{T} 1^{(1)}$ & $1.93 \mathrm{bA}^{*}$ & $0.01 \mathrm{~dB}$ \\
\hline $\mathrm{T} 2$ & $2.16 \mathrm{bA}$ & $0.46 \mathrm{cB}$ \\
\hline $\mathrm{T} 3$ & $0.06 \mathrm{dA}$ & $0.00 \mathrm{dA}$ \\
\hline $\mathrm{T} 4$ & $2.30 \mathrm{bA}$ & $1.16 \mathrm{bB}$ \\
\hline $\mathrm{T} 5$ & $0.00 \mathrm{dA}$ & $0.00 \mathrm{dA}$ \\
\hline T6 & $3.15 \mathrm{aA}$ & $2.56 \mathrm{aA}$ \\
\hline $\mathrm{T} 7$ & $1.18 \mathrm{cA}$ & $0.01 \mathrm{~dB}$ \\
\hline
\end{tabular}

$\mathrm{CV}(\%) \quad 6.62$

(1) T1 - No use of dormancy breaking; $\mathrm{T} 2$ - Gibberellic acid $\left(200 \mathrm{mg} \mathrm{L}^{-1}\right)$ for one hour; T3 - Stratification at $5^{\circ} \mathrm{C}$ for 30 days; T4 - Immersion in water at room temperature for 24 hours; T5 - Chemical scarification with sulfuric acid (96\%) for 5 minutes; T6 - Scarification with sandpaper; 77 - Immersion in hot water $\left(80^{\circ} \mathrm{C}\right)$ for 5 minutes.

*Averages with different lowercase letters in the same column and upper case in row differ by Tukey test $(\alpha=0.05)$.

Table 4. Average germination time (days) of E. candoleana seeds according to the photoperiod and technique for breaking dormancy.

\section{Photoperiod}

\begin{tabular}{ccc}
\hline Treatments & 0 hours & 24 hours \\
\hline T1 $^{(1)}$ & $12.19 \mathrm{bB}^{*}$ & $39.00 \mathrm{aBC}$ \\
$\mathrm{T} 2$ & $11.15 \mathrm{aB}$ & $15.47 \mathrm{aCD}$ \\
$\mathrm{T} 3$ & $19.91 \mathrm{bB}$ & $77.00 \mathrm{aA}$ \\
$\mathrm{T} 4$ & $10.98 \mathrm{aB}$ & $12.32 \mathrm{aCD}$ \\
$\mathrm{T} 5$ & $77.00 \mathrm{aA}$ & $77.00 \mathrm{aA}$ \\
$\mathrm{T} 6$ & $6.48 \mathrm{aB}$ & $6.61 \mathrm{aD}$ \\
$\mathrm{T} 7$ & $11.50 \mathrm{bB}$ & $61.33 \mathrm{aAB}$ \\
\hline
\end{tabular}

\section{$\mathrm{CV}(\%)$}

37.60

(1) T1 - No use of dormancy breaking; T2 - Gibberellic acid $\left(200 \mathrm{mg} \mathrm{L}^{-1}\right)$ for one hour; T3 - Stratification at $5^{\circ} \mathrm{C}$ for 30 days; T4 - Immersion in water at room temperature for 24 hours; T5 - Chemical scarification with sulfuric acid (96\%) for 5 minutes; T6 - Scarification with water sandpaper; T7 - Immersion in hot water $\left(80^{\circ} \mathrm{C}\right)$ for 5 minutes.

*Averages with different lowercase letters in the same row and upper case in column differ by Tukey's test $(\alpha=0.05)$. 


\section{PHYSIOLOGICAL CHARACTERIZATION AND CONSERVATION OF SEEDS OF Eugenia candolleana}

(MYRTACEAE)

For germination and GSI of E. candoleana, it was verified that the seeds kept in photoperiod of 24 hours resembled statistically of those without photoperiod when the technique of scarification with sandpaper was adopted. On the other hand, the absence of photoperiod prevailed as superior for this variable in the treatments with cold stratification, by means of hot water and water in natural temperature, gibberellic acid and without any type of procedure (Tables 2 and 3, respectively).

Among the seeds kept in the dark, superiority for germination was observed in those that were not submitted to techniques for breaking dormancy, immersion in gibberellic acid and water at room temperature, as well as in the scarified ones with sandpaper, obtaining values between 70 and $81 \%$. Under light, only techniques of immersion in water with ambient temperature and scarification with sandpaper were statistically superior, but with germination between 55 and 62\%, respectively (Table 2).

This superiority in germination of the seeds with the use of gibberellic acid must have occurred due to the stimulation by gibberellin for the synthesis of enzymes that digest the stored endosperm, forming the sugars, amino acids and nucleic acids that are absorbed and transported to the growing regions of the embryo, stimulating the cell elongation, causing the root to rupture the seed coat faster, thus accelerating the germination, with uniformity, as described by Hopkins (1999).

The sandpaper procedure basically consists of subjecting the seeds to abrasion, which will deplete the seed coat, providing conditions to absorb water faster and accelerate the germination process (FOWLER \& BIANCHETTI, 2000), a fact proven in the present work.

However, the use of sulfuric acid and stratification at $5^{\circ} \mathrm{C}$ was detrimental to the embryo of the seeds tested, since adequate germination was not observed (Table 2).

It is believed that sulfuric acid, although successfully used in other species (FLORIANO et al., 2004; ALVES et al., 2000; RIBAS et al., 1996; SANTAREM\& AQUILA, 1995; EIRA et al., 1993; MARTINS et al., 1992), may have damaged the embryo making it unfeasible. On the other hand, the use of low temperature may have induced the seed to fall into secondary dormancy, increasing the content of inhibitors such as ABA (abscisic acid), necessitating more time to initiate germination, a fact observed in the absence of light (Table 2). Secondary dormancy is characterized by the exit of the seed of the plant without its presence, however by some factor this is induced to appear in the same. This may be a technique to try to conserve it for a longer period while storing its seeds.

Moreover, the treatment with hot water was also harmful in the seeds kept under light, believing that the enzymes synthesized under these conditions have been denatured by the higher temperature 
(DOUSSEAU et al., 2008). With this, it is believed that the seed may be using differentiated enzymes for the same metabolic route, being those produced in the dark more tolerant to higher temperature.

In relation to AGT, the maximum time of evaluation in days was used as AGT in the treatments in which there was no germination, being 77 (Table 4).

In the absence of the photoperiod (0 hours), the use of chemical scarification with sulfuric acid (96\%) for 5 minutes did not show germination of the seeds, for this treatment the higher AGT, for the other seed dormancy breaking treatments there were no significant differences. With the 24-hour photoperiod, the major AGTs were stratified at $5^{\circ} \mathrm{C}$ for 30 days and chemical scarification with sulfuric acid (96\%) for 5 minutes, and the lower AGT with the scarification of with sandpaper, which also did not differ from seed immersion in water at room temperature for 24 hours and the use of gibberellic acid (200 $\mathrm{mg} \mathrm{L}^{-1}$ ) for one hour (Table 4).

Observing each treatment for dormancy breaking according to the photoperiod, the use of stratification at $5^{\circ} \mathrm{C}$ for 30 days, immersion in hot water $\left(80^{\circ} \mathrm{C}\right)$ for five minutes and the control, showed the lowest AGT without photoperiod adoption of 24 hours. With the use of gibberellic acid (200 $\left.\mathrm{mg} \mathrm{L}^{-1}\right)$ for one hour, immersion of the seeds in water at room temperature for 24 hours and scarification with sandpaper, there were no significant differences between photoperiods ( 0 and 24 hours). In addition, for chemical scarification with sulfuric acid $(96 \%)$ for 5 minutes, there were no differences either, but for this treatment there was no seed germination (Table 4).

In seeds of Passiflora genus, specific treatments applied to the tegument of the seeds that cause the rupture or its weakening can reduce the time necessary for the germination and consequently reduce the time for the germination of the seedlings (ALEXANDRE et al., 2009). As is the case of the positive effect of some of these treatments in the present experiment.

For the accumulated germination of the seeds (Figure 3), there was an increase in the percentage of germinated seeds up to a certain period, being basically until the $30^{\text {th }}$ day in the absence of the photoperiod, and until the $20^{\text {th }}$ day with the photoperiod of 24 hours, stabilizing after these periods. So, it was observed higher germination accumulated in the absence of the photoperiod of 24 hours. 

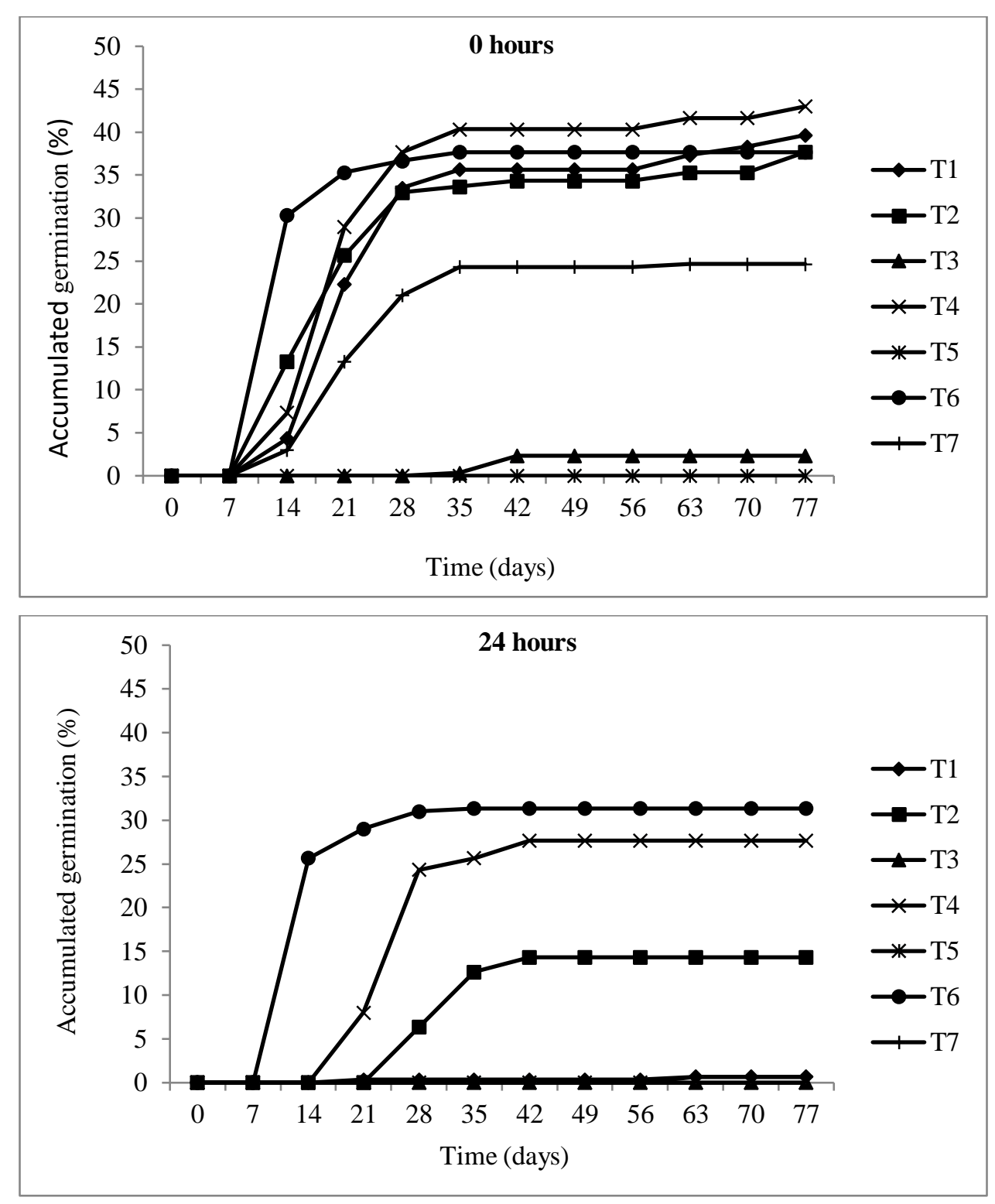

Figure 3. Accumulated germination (\%) of E. candoleana seeds, according to the photoperiod (0 and 24 hours) and treatments for dormancy breaking.

\section{CONCLUSION}

Reducing the moisture content of E. candoleana seeds reduce their viability, being important not to be reduced more than $20 \%$ from their initial content.

The seeds did not present dormancy, since the treatments used did not differentiate from the control. However, under certain conditions there may be stimulus for secondary dormancy entry through stratification with the absence of photoperiod.

The use of sulfuric acid in both photoperiod conditions is not recommended. 


\section{REFERENCES}

ALEXANDRE, R. S.; GONÇALVES, F. G.; ROCHA, A. P.; ARRUDA, M. P. DE; LEMES, E. DE Q. 2009. Tratamentos físicos e químicos na superação de dormência em sementes de Enterolobium contortisiliquum (Vell.) Morong. Revista Brasileira de Ciências Agrárias, Recife, v.4, n.2, p.156159.

ALVES, M.C.S.; MEDEIROS-FILHO, S.; ANDRADE-NETO, M.; TEÓFILO, E.M. 2000. Superação da dormência em sementes de Bauhinia monandra Britt e Bauhinia ungulata L.-Caesalpinoideae. Revista Brasileira de Sementes, Brasília, v.22, p.139-144.

ANDRADE, A.C.S.; CUNHA, R.; SOUZA, A.F.; REIS, R.B.; ALMEIDA, K.L. 2003. Physiological and morphological aspects of seed viability of a neotropical savannah tree, Eugenia dysenterica DC. Seed Science and Technology, Zürich, v.31, p.125-137.

BRASIL. 2009. Ministério da Agricultura, Pecuária e Abastecimento. Regras para Análise de Sementes. Secretaria de Defesa Agropecuária. Brasília, DF: Mapa/ACS, 395p.

CASSOL, D.A.; PIROLA, K.; ALEGRETTI, A.L.; OLIVEIRA, J.S.M.; PANATTO, E.; WAGNER JÚNIOR, A. 2012. Teste de Aceitabilidade de duas Geleias de Ameixa da Mata por meio de Análise Sensorial. In: Congresso Brasileiro de Fruticultura, Bento Gonçalves. Anais, XXII Congresso Brasileiro de Fruticultura.

DELGADO, L.F.; BARBEDO, C.J. 2007. Tolerância à dessecação de sementes de espécies de Eugenia. Pesquisa Agropecuária Brasileira, Brasília, v.42, p.265-272.

DOUSSEAU, S.; ALVARENGA, A.A.; ARANTES, L.O.; OLIVEIRA, D.M.; NERY, F.C. 2008. Germinação de sementes de tanchagem (Plantago tomentosa Lam.): influência da temperatura, luz e substrato. Ciência e Agrotecnologia, Lavras, v.32, p.438-443.

EIRA, M.T.S.; FREITAS, R.W.A.; MELLO, C.M.C. 1993. Superação da dormência de sementes de Enterolobium contortisiliquum (VELL.) Morong. -Leguminosae. Revista Brasileira de Sementes, Brasília, v.15, p.177-181.

FLORIANO, E.P. 2004.Germinação e dormência de sementes florestais. Santa Rosa: ANORGS, 1 ed. (Caderno didático). $19 \mathrm{p}$.

FOWLER, J.A.P.; BIANCHETTI, A. 2000. Dormência em sementes florestais. Colombo: EMBRAPAFlorestas (Documento 40). $27 \mathrm{p}$.

FRANZON, R.C.; CAMPOS, L.Z.O.; PROENÇA, C.E.B.; SOUZA-SILVA, J.C. 2009. Araçás do Gênero Psidium: principais espécies, ocorrência, descrição e usos. 48 p.

FRANZON, R. C.; CAMPOS, L.Z.O.; PROENÇA, C.E.B.; SOUSA-SILVA, J.C. 2009. Araçás do gênero Psidium : principais espécies, ocorrência, descrição e usos. Brasília, DF: Embrapa Cerrados. (Série Documentos, Embrapa). 48 p.

GENTIL, D.F.O.; FERREIRA, S.A.N. 1999. Viabilidade e superação da dormência em sementes de araçá-boi (Eugenia stipitata ssp. sororia). Acta Amazonica, Manaus, v.29, p.21-31.

HOPKINS, W.G.1999.The role of hormones in plant development. In: Introduction to plant physiology. New York: John Wiley e Sons. 528 p.

LEITE-LEGATTI, A.V.; BATISTA, A.G.; DRAGANO, N.R.V.; MARQUES, A.C.; MALTA, L.G.; RICCIO, M.F.; EBERLIN, M.N.; MACHADO, A.R.T.; CARVALHO-SILVA, L.B.; RUIZ, A.L.T.G.; CARVALHO, J.E.; PASTORE, G.M.; MARÓSTICA JÚNIOR, M.R. 2012. Jabuticaba peel: Antioxidant compounds, antiproliferative and antimutagenic activities. Food Research International, Essex, v.49, p.596-603.

LIMA, A.J.B.; CORREAA, A.D.; SACZK, A.A.; MARTINS, M.P.; CASTILHO, R.O. 2011. Anthocyanins, pigment stability and antioxidant activity in jabuticaba [Myrciaria cauliflora (mart.) o. berg]. Revista Brasileira de Fruticultura, Jaboticabal, v. 33, p.877-887. 
LORENZI, H.; SARTORI, S.; BACHER, L.B.; LACERDA, M. 2006. Frutas brasileiras e exóticas cultivadas: de consumo in natura. São Paulo: Instituto Plantarum de Estudos da Flora. 640 p.

MAGALHÃES, M.M.; BARROS, R.S.; FINGER, F.L. 1996. Changer in nonstructural carbohydrates in developing fruit of Myrciaria jaboticaba. Scientia Horticulturae, Amsterdam, v.66, p.17-22.

MAGUIRE, J.D. 1962. Speed of germination aid in selection and evaluation for emergence and vigour. Crop Science, Madison, v.2, p.176-177.

MANICA, I. 2002. Frutas Nativas, Silvestres e Exóticas 2: técnicas de produção e mercado: feijoa, figo- da- índia, fruta-pão, jaca, lichia, mangaba. Porto Alegre: Cinco Continentes Editora, p. 459-541.

MARIN, R.; PIZZOLI, G.; LIMBERGER, R.; APEL, M.; ZUANAZZI, J.A.S.; HENRIQUES, A.T. 2004. Propriedades nutracêuticas de algumas espécies frutíferas nativas do sul do Brasil. In: RASEIRA, M.C.B.; ANTUNES, L.E.C.; TREVISAN, R.; GONÇALVES, E.D. Espécies frutíferas nativas do sul do Brasil. Pelotas: Embrapa Clima Temperado. p.107-122. (Documentos, 129).

MARTINS, C.C.; CARVALHO, N.M.; OLIVEIRA, A.P. 1992. Quebra de dormência de sementes de sabiá (Mimosa caesalpiniaefolia Benth.). Revista Brasileira de Sementes, Brasília, v.14, p.5-8.

MELO, E.A.; MACIEL, M.I.S.; LIMA, V.L.A.G.; NASCIMENTO, R.J. 2008a. Capacidade antioxidante de frutas. Revista Brasileira de Ciências Farmacêuticas, São Paulo, v.44, p.193-201.

MELO, E.A.; MACIEL, M.I.S.; LIMA, V.L.A.G.; ARAÚJO, C.R. 2008b. Teor de fenólicos totais e capacidade antioxidante de polpas congeladas de frutas. Alimentos e Nutrição, Araraquara, v.19, p.67-72.

NAUTIYAL, A.R.; PUROHIT, A.N. 1985. Seed viability in sal. II. Physiological and biochemical aspects of ageing in seeds of Shorea robusta. Seed Science and Technology, Zuric, v.13, p.69-76.

RIBAS, L.L.F.; FOSSATI, L.C.; NOGUEIRA, A.C. 1996. Superação da dormência de sementes de Mimosa bimucronata (DC.) O. Kuntze (maricá). Revista Brasileira de Sementes, Brasília, v.18; p.98-101.

ROESLER, R.; MALTA, L.G.; CARRASCO, L.C.; HOLANDA, R.B.; SOUSA, A.S.; PASTORE, G.M. 2007. Atividade antioxidante de frutas do cerrado. Ciência e Tecnologia de Alimentos, Campinas, v.27, p.53-60.

RUFINO, M.S.M.; ALVES, R.E.; BRITO, E.S.; PEREZ-JIMENEZ, J.; SAURA-CALIXTO, F.; MANCINI- FILHO, J. 2010. Bioactive compounds and antioxidant capacities of 18 non-traditional tropical fruits from Brazil. Food Chemistry, Barking, v.121, p.996-1002.

RUFINO, M.S.M.; ALVES, R.E.; FERNANDES, F.A.N.; BRITO, E.S. 2011. Free radical scavenging behavior of ten exotic tropical fruits extracts. Food Research International, Essex, v.44, p.20722075.

SANTAREM, E.R.; AQUILA, M.E.A. 1995. Influência de métodos de superação de dormência e do armazenamento na germinação de sementes de Senna macranthera (Colladon) Irwin \& Barneby (Leguminosae). Revista Brasileira de Sementes, Brasília, v.17, p.205-209.

SCALON, S. P. Q.; NEVES, E. M. S.; MASETO, T. L.; PEREIRA, V. Z. 2012. Sensibilidade à dessecação e ao armazenamento em sementes de Eugenia pyriformis Cambess. (Uvaia). Revista Brasileira de Fruticultura, Jaboticabal, v.34, n.1, p.269-276.

SILVA, J.B.C., NAKAGAWA, J. 1995. Estudo de fórmulas para o cálculo da velocidade de germinação. Informativo ABRATES, v.5. n.1, p.62-73.

STUBSGAARD, F. (1990). Seed moisture. Humlebaek: DFSC, 30p.

VALIO, I.F.M.; FERREIRA, Z.L. 1992. Germination of seeds of Myrciaria cauliflora (Mart.) Berg. (Myrtaceae). Revista Brasileira de Fisiologia Vegetal, Lavras, v.4, p.95-98. 
WAGNER JÚNIOR, A.; FRANZON, R.C.; SILVA, J.O.C.; SANTOS, C.E.M.; GONÇALVES, R.S.; BRUCKNER, C.H. 2007. Efeito da temperatura na germinação de sementes de três Espécies de jabuticabeira. Revista Ceres, Viçosa, v.54, p.345-350.

ZONTA, E.P.; MACHADO, A.A. 1984. Sanest - Sistema de Análise Estatística para Microcomputadores. Pelotas: UFPel. 75p.

Received in: December 11, 2015 Accepted in: March 12, 2018 